\title{
Sebaran Pola Pertumbuhan Ikan Red Devil (Amphilophus sp) Di Kawasan Danau Batur, Bali
}

\author{
I Wayan Juliawan a*, I Wayan Arthana a , Endang Wulandari Suryaningtyas a \\ ${ }^{a}$ Program Studi Manajemen Sumberdaya Perairan, Fakultas Kelautan dan Perikanan, Universitas Udayana, Bukit \\ Jimbaran, Bali- Indonesia \\ *Email: wayanjuliawan779@gmail.com \\ Diterima (received) 8 Januari 2020; disetujui (accepted) 30 Juni 2020; tersedia secara online (available online) 1 Agustus 2020
}

\begin{abstract}
Batur Lake is one of the lakes located in the Kintamani sub-district, Bali. This lake has abundant biodiversity, one of them is Red Devil fish (Amphilophus sp) which is a competitor of native and introduced fish. The research aims to find out the pattern of growth, size structure, and the physical and chemical conditions of waters. The method used was descriptive quantitative by using two trapping devices that were fishing rods and nets. Calculation results showed that a wide range of growth patterns of Red Devil (Amphilophus sp) fish on both trapping devices (fishing rods and nets) were grouped $(\operatorname{Id}<1)$. The highest sized structure value on the trapping devices (fishing rod) found in the water of Trunyan Village that was total length (TL) of $9,3 \mathrm{~cm}$, Standard length (SL) of 7,3 cm, and weight: 16,5 gr. On the trapping devices (net) the highest value was found in the water of Songan Village that was total length (TL) of 13,5 , SL of 11,1 , and weight: 48,8 gr. The growth patterns of Red Devil (Amphilophus sp) fish based on length and weight analysis showed that were partly positive allometric and partly negative allometric. The result of the water quality measurement in the water of Batur Lake was about $26,3^{\circ} \mathrm{C}-29,1^{\circ} \mathrm{C}$ (temperature), $5,36 \mathrm{mg} / \mathrm{L}-6 \mathrm{mg} / \mathrm{L}$, (DO), 7,2 - 7,8 (pH), and $87,1 \mathrm{~cm}-147,8 \mathrm{~cm}$ (brightness).
\end{abstract}

Keywords: Red Devil; pattern of growth; size structure; Batur Lake

\begin{abstract}
Abstrak
Danau Batur merupakan salah satu danau yang terletak di Kecamatan Kintamani, Bali. Danau ini memiliki keanekaragaman hayati yang melimpah, salah satunya adalah Ikan Red Devil (Amphilophus $s p$ ) yang merupakan kompetitor ikan asli dan introduksi. Penelitian ini bertujuan untuk mengetahui sebaran pola pertumbuhan Ikan Red Devil, struktur ukuran, serta kondisi fisika dan kimia perairan. Metode yang digunakan adalah deskriptif kuantitatif dengan menggunakan dua alat tangkap yaitu jaring dan pancing. Hasil perhitungan menunjukkan bahwa sebaran pola pertumbuhan Ikan Red Devil pada kedua alat tangkap (jaring dan pancing) bersifat mengelompok (Id > 1). Nilai struktur ukuran tertinggi pada alat tangkap pancing dijumpai pada perairan Desa Trunyan, yaitu panjang total (PT): $9,3 \mathrm{~cm}$, panjang standar (PS) : 7,3 cm, dan berat: $16,5 \mathrm{~g}$. Pada alat tangkap jaring nilai tertinggi dijumpai pada perairan Desa Songan yaitu panjang total (PT): 13,5 cm, PS: 11,1 cm, dan Berat 48,8 g. Pola pertumbuhan Ikan Red Devil (Amphilophus sp) berdasarkan analisis panjang dan berat menunjukkan pola pertumbuhan yang sebagian allometrik positif dan sebagian lagi allometrik negatif. Hasil pengukuran parameter kualitas air di perairan Danau Batur berkisar $26,3^{\circ} \mathrm{C}-29,1^{\circ} \mathrm{C}$ (suhu), 5,36-6 mg/L (DO), 7,2 -7,8 (pH), dan 87,1-147,8 cm (kecerahan)
\end{abstract}

Kata Kunci: Red devil, sebaran pola pertumbuhan, struktur ukuran, Danau Batur

\section{Pendahuluan}

Indonesia memiliki lebih dari 500 danau dengan luas total $\pm 5.000 \mathrm{~km}^{2}$ atau sekitar $0,25 \%$ luas daratan. Keseluruhan danau tersebut mengandung $500 \mathrm{~km}^{3}$ sumber air. Danau di Indonesia kaya dengan

doi: https://doi.org/10.24843/blje.2020.v20.i02.p05

(C) 2019 by the authors; Content from this work may be used under the terms of the Creative Commons Attribution 3.0 licence. Any further distribution of this work must maintain attribution to the author(s) and the title of the work, journal citation and DOI. Published under licence by Udayana University, Indonesia. 
keragaman fungsi dan keanekaragaman hayati, termasuk berbagai jenis ikan yang hidup di dalamnya yang dapat menjadi sumber protein hewani bagi penduduk lokal.

Salah satu danau di Indonesia yang memiliki keanekaragaman hayati yang sangat tinggi adalah Danau Batur. Danau Batur merupakan danau yang terletak di Kecamatan Kintamani, Kabupaten Bangli, Provinsi Bali. Danau Batur termasuk jenis danau kaldera aktif yang berada di ketinggian $1.031 \mathrm{~m}$ di atas permukaan laut. Danau tersebut telah dimanfaatkan oleh masyarakat di sektor perikanan, pertanian, dan pariwisata.

Kegiatan introduksi ikan melalui penebaran, sering dilakukan di Danau Batur, namun awal keberadaan ikan introduksi di danau tersebut tidak diketahui secara pasti karena ketiadaan informasi mengenai kondisi sumber daya ikan sebelum introduksi.Menurut Wijaya et al. (2011), Jenis ikan yang sering ditebar di Danau Batur umumnya merupakan jenis ikan ekonomis penting seperti Ikan Nila (Oreochromis niloticus), Ikan Mas (Cyprinus carpio),Ikan Mujair (Oreochromis mossambicus), Ikan Tawes (Puntius javanicus),dan Ikan Graskap (Ctenophryngodon idella). Ikan yang sering tertangkap oleh nelayan ataupun pemancing di Danau Batur yaitu Ikan Nila (Oreochromis niloticus), Ikan Mas (Cyprinus carpio), Ikan Mujair (Oreochromis mossambicus) yang bernilai ekonomis serta Ikan Red Devil (Amphilophus sp) yang tidak di perjualbelikan.

Ikan Red Devil (Amphilophus sp) merupakan jenis ikan pemangsa daging yang memiliki gigi tajam, berwarna orange, hitam, putih, silver, kuning, bahkan ada juga yang berwarna campuran dari warnawarna tersebut. Ikan Red Devil disebut sebagai ikan predator bagi ikan-ikan kecil lainnya. Sehingga Ikan Red Devil disebut sebagai hama, karena merupakan ikan yang hanya bisa memangsa namun tidak menghasilkan nilai ekonomi yang memadai, serta perkembangbiakannya sangat cepat (Fatma, 2017). Hal yang dikawatirkan, ikan ini dapat mendominansi jenis ikan yang terdapat di kawasan Danau Batur dan akan menyebabkan ekosistem yang terdapat di kawasan tersebut menjadi terganggu.

Menurut Habibie dkk. (2015) Ikan Red Devil merupakan kompetitor ikan asli dan introduksi serta predator ganas bagi ikan-ikan asli yang berukuran kecil. Meningkatnya populasi Ikan Red Devil menyebabkan struktur populasi ikan bergeser, keragaman ikan menurun, dan rantai makanan menjadi panjang. Untuk meminimalisir terjadinya dominansi Ikan Red Devil di kawasan Danau Batur, sangat penting untuk melakukan penelitian dasar mengenai sebaran pola pertumbuhan dan struktur ukuran Ikan Red Devil di kawasan Danau Batur. Penelitian ini diharapkan dapat memberikan kontribusi mengenai pengelolaan kawasan Danau Batur agar ekosistem danau tetap lestari.

Tujuan dari penelitian ini yaitu untuk mengetahui sebaran pola pertumbuhan Ikan Red Devil (Amphilophus sp) dan struktur ukuran (panjang dan bobot) yang ditemukan di kawasan Danau Batur, Bali.

\section{Metode Penelitian}

\subsection{Waktu dan lokasi penelitian}

Penelitian ini dilakukan di Danau Batur yang terletak di Kecamatan Kintamani, Kabupaten Bangli, Provinsi Bali pada Bulan September hingga November 2018. Pengambilan sampel Ikan Red Devil (Amphilophus sp) dilakukan di 5 perairan, yang meliputi perairan Desa Songan, Desa Batur, Desa Kedisan, Desa Abang, dan Desa Trunyan.

\subsection{Alat dan bahan}

Alat yang digunakan dalam penelitian yaitu GPS, jaring (gill net), pancing, penggaris, jangka sorong, timbangan digital, alat tulis, nampan, plastik, kertas label, pH meter, DO meter, dan Secchi disk. Bahan yang digunakan yaitu tissue, aquades, sampel kualitas air, dan sampel ikan.

\subsection{Metode pengambilan data}

Penelitian mengenai sebaran pola pertumbuhan, dan struktur ukuran Ikan Red Devil (Amphilophus $s p$ ) berdasarkan analisis panjang dan bobot dilakukan dengan menggunakan metode deskriptif kuantitatif dan metode penentuan perairan menggunakan metode purposive sampling. 


\subsubsection{Pengambilan sampel Ikan Red Devil}

Pengambilan sampel Ikan Red Devil dilakukan dengan menggunakan dua (2) jenis alat tangkap, berupa jaring insang (gill net) dan pancing. Jaring insang (gill net) yang digunakan memiliki ukuran panjang $100 \mathrm{~m}$, lebar $1 \mathrm{~m}$, dan tinggi $1 \mathrm{~m}$ dengan ukuran mata jaring $3 \mathrm{~cm}$. Jaring dipasang pada titik yang telah ditentukan dengan jarak $15 \mathrm{~m}$ dari pinggir danau, kemudian proses penggiringan ikan dengan cara memukul permukaan air. Selanjutnya pengecekan jaring, jaring diangkat dan Ikan yang tertangkap disimpan dalam box yang telah diberi es untuk kemudian di analisa. Alat tangkap pancing dioperasikan pada pinggir kawasan danau dan penggunaanya dibatasi sampai 5 jam. Ikan yang diperoleh selama selang waktu tersebut dilepaskan dari pancing kemudian dilakukan analisa.

Semua ikan yang tertangkap dikelompokan menurut jenis alat tangkap yang digunakan. Ikan yang tertangkap pada masing-masing alat tangkap dihitung jumlah yang diperoleh serta dilakukan pengukuran panjang dan bobotnya.

\subsubsection{Pengukuran panjang Bobot Ikan Red Devil}

Tahap pertama yang dilakukan adalahmelakukan identifikasi Ikan Red Devil yang mengacu pada fishbase. Kemudian mengukur panjang total (TL) terhadap semua Ikan Red Devil yang tertangkap dengan menggunakan penggaris. Panjang total (TL) diukur dengan cara mengukur panjang ikan dari ujung mulut terdepan sampai dengan ujung sirip ekor. Sedangkan untuk mengukur bobot basah ikan, alat yang digunakan adalah timbangan digital dengan ketelitian $0,1 \mathrm{~g}$.

\subsubsection{Pengambilan data parameter fisik dan kimia perairan}

Pengambilan data parameter kualitas air dilakukan secara in situ bersamaan dengan pengambilan data Ikan Red Devil. Adapun Parameter kualitas air yang diukur meliputi oksigen terlarut (DO), pH, suhu, dan kecerahan. Pengukuran parameter tersebut dilakukan sebanyak 4 kali pengulangan.

\subsection{Analisa data}

\subsubsection{Indeks Penyebaran Morisita}

Menurut Brower et al. (1990) pola distribusi Ikan Red Devil dapat dihitung dengan menggunakan rumus indeks penyebaran Morisita (Id) sebagai berikut:

$$
\mathrm{Id}=\mathrm{n} \frac{\sum \mathrm{x}^{2}-\mathrm{N}}{\mathrm{N}(\mathrm{N}-1)}
$$

dimana Id adalah Indeks distribusi morisita; $\mathrm{n}$ adalah jumlah seluruh perairan pengambilan sampel; $\mathrm{N}$ adalah jumlah seluruh individu, dan $\backslash$ sum $\mathrm{x} 2$ adalah jumlah kuadrat jenis ke 1 per perairan untuk total $\mathrm{n}$ perairan. Kriteria pola sebaran Morisita sebagai berikut (Brower et al., 1990):

Id $=1 \quad$ : Pola sebaran individu bersifat acak

Id $>1$ : Pola sebaran individu bersifat mengelompok

$\mathrm{Id}<1 \quad$ : Pola sebaran individu bersifat seragam

\subsubsection{Hubungan panjang dan bobot Ikan Red Devil}

Hubungan panjang dan bobot Ikan Red Devil dianalisis menggunakan rumus sebagai berikut (Effendie, 2002):

$$
\mathrm{W}=\mathrm{aL}^{\mathrm{b}}
$$


Dimana $\mathrm{W}$ adalah bobot $(\mathrm{g})$, L adalah Panjang $(\mathrm{cm})$, a adalah Intersep (perpotongan hubungan kurva panjang bobot dengan sumbu $y$ ), dan $b$ adalah pendugaan pola pertumbuhan panjang bobot. Nilai $a$ dan $b$ diduga dari bentuk linier persamaan di atas, yaitu:

$$
\log \mathrm{W}=\log \mathrm{a}+\mathrm{b} \log \mathrm{L}
$$

Untuk menguji nilai $b \geq 3$ atau $b<3$ digunakan uji-t dengan hipotesis:

$\mathrm{b}=3$, hubungan panjang dengan bobot adalah isometrik (pertumbuhan panjang sama dengan pertumbuhan bobot).

$\mathrm{b} \neq 3$, hubungan panjang dengan bobot adalah allometrik.

Pola pertumbuhan allometrik ada dua macam yaitu allometrik positif apabila $b>3$, alometrik positif yang dinyatakan bahwa pertambahan bobot lebih dominan daripada pertambahan panjang. Allometrik negative apabila $b<3$ yang berarti bahwa pertambahan panjang lebih dominan daripada pertambahan bobotnya.

\section{Hasil dan Pembahasan}

\subsection{Sebaran pola pertumbuhan Ikan Red Devil (Amphilophus sp)}

Hasil analisis sebaran pola pertumbuhan Ikan Red Devil (Amphilophus sp) dengan menggunakan Indeks penyebaran Morisita pada alat tangkap pancing dan jaring menunjukan nilai hasil analisis yang tidak jauh berbeda yaitu 1,05 untuk alat tangkap pancing 1,185 untuk alat tangkap jaring, yang mengindikasikan bahwa penyebaran pola pertumbuhan Ikan Red Devil bersifat mengelompok (Tabel 1).

Hal ini kemungkinan karena adanya kondisi perairan dan habitat yang hampir sama di seluruh kawasan Danau Batur. Sehingga distribusi Ikan Red Devil (Amphilophus sp) menyebar merata pada semua kawasan perairan. Selain itu, kemungkinan juga disebabkan oleh ketersedian pakan yang merata pada setiap perairan dan ada yang menarik dengan jenis ikan yang tertangkap di perairan Desa Batur yaitu jenis ikan albino. Menurut Ludwig dan Reynolds (1988), faktor yang dapat mempengaruhi pola sebaran spasial makhluk hidup, yaitu: (a) Faktor vektorial, yaitu faktor yang dihasilkan oleh aksi lingkungan (jenis tanah, angin, intensitas cahaya dan air); (b) Faktor sosial, yaitu faktor yang berkaitan dengan perilaku organisme seperti territorial; (c) Faktor co-aktif, yaitu faktor yang berkaitan dengan interaksi intraspesifik; (d) Faktor stokastik, yaitu faktor yang dihasilkan dari variasi acak pada beberapa factor. Pada suatu perairan serta ketersediaan makanan ikut mempengaruhi organisme hidup pada habitatnya.

Tabel 1. Hasil Analisis Indeks Penyebaran Morisita.

\begin{tabular}{clcl}
\hline No & Jenis Alat Tangkap & Nilai Indeks Morisita & Keterangan \\
\hline 1. & Pancing & 1,035 & Seragam (Id > 1) \\
2. & Jaring & 1,185 & Seragam (Id $>1)$ \\
\hline
\end{tabular}

Hasil tangkapan Ikan Red Devil (Amphilophus sp) pada semua perairan memperlihatkan bahwa hasil tangkapan antar perairan adalah beragam (Gambar 1). 
IW Juliawan, dkk.; Sebaran pola pertumbuhan Ikan Red Devil (Amphilophus sp).....

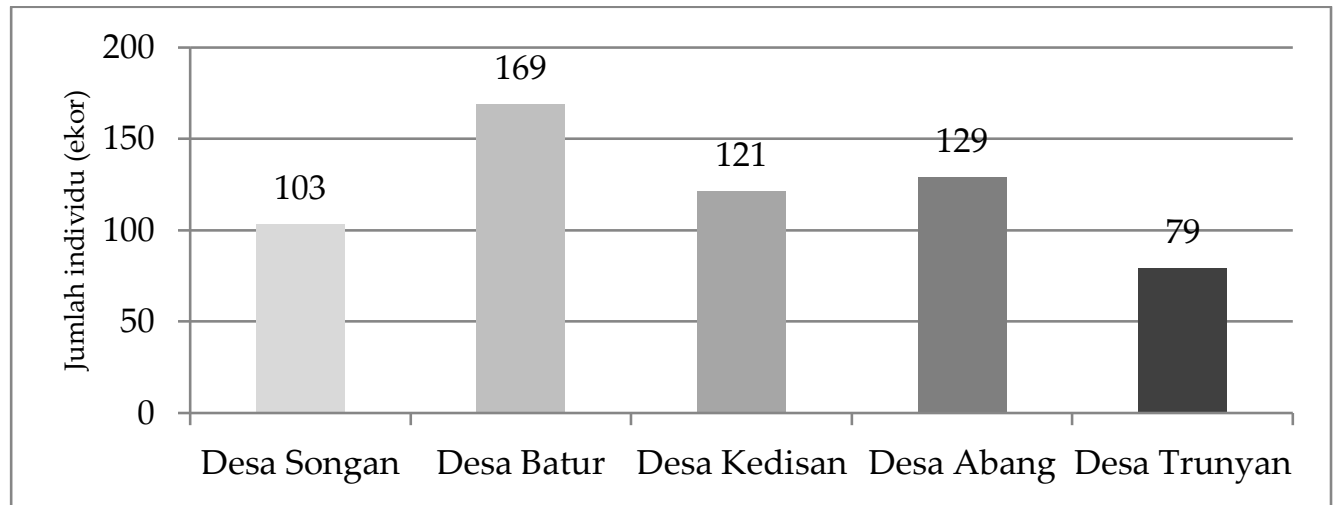

Gambar 1. Perbandingan hasil tangkapan Red Devil (Amphilophus sp) antar perairan.

Hasil tangkapan terbanyak di peroleh di perairan Desa Batur sebanyak 169 ekor, kemungkinan dikarenakan memiliki subtrat berbatu yang bergoa-goa dan sekaligus sebagai tempat berlindung dan memijah. Menurut Conkel (1993), Ikan Zebra (famili Cichlidae) menyenangi perairan berbatu dan sering ditemukan berlindung pada celah-celah retakan batuan atau pada akar tumbuhan dan ranting pohon yang jatuh. Di perairan Desa Trunyan dengan subtrat yang tanpa bebatuan ditemukan ikan yang lebih sedikit yang hanya sebanyak 79 ekor. Disamping itu, keberadaan ikan di Desa Trunyan, mungkin berkaitan dengan permukiman yang padat dan aktivitas pariwisata yang menyebabkan ikan yang berada di Desa Trunyan tersebut susah ditangkap dengan menggunakan alat tangkap pancing. Ada yang menarik pada Ikan Red Devil (Amphilophus sp) yang tertangkap di Desa Trunyan yaitu memiliki warna yang lebih terang dari pada di perairan lainnya (Gambar 2).

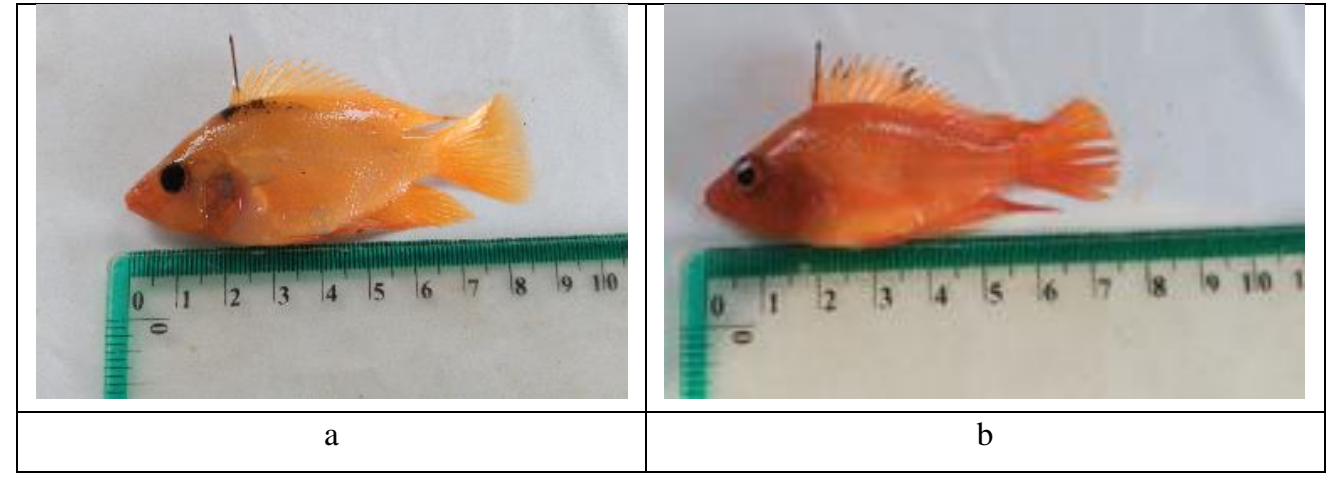

Gambar 2. (a) Ikan Red Devil (b) Ikan Red Devil yang tertangkap di perairan Desa Trunyan.

\subsection{Struktur ukuran Ikan Red Devil (Amphilophus sp)}

Rata-rata panjang total (PT) Ikan Red Devil (Amphilophus sp) pada alat tangkap pancing dengan ukuran terpanjang dijumpai di perairan Desa Trunyan dengan ukuran 9,3 cm dan rata-rata terpendek terdapat di perairan Desa Kedisan dengan ukuran 8,5 cm (Tabel 2). Berat Ikan Red Devil yang mancapai berat sampai 16,5 g diperoleh di perairan Desa Trunyan.

Ukuran rata-rata panjang total (PT) Ikan Red Devil (Amphilophus sp) pada alat tangkap jaring dengan nilai tertinggi terdapat pada perairan Desa Songan dengan ukuran 13,5 cm dan terendah terdapat di perairan Desa Trunyan dengan ukuran 11,7 cm. Berat Ikan Red Devil (Amphilophus sp) tertinggi dijumpai di perairan Desa Songan dengan berat 48,8 g dan terendah terdapat di perairan Desa Trunyan dengan berat 31,4 g (Tabel 3). 
Rata rata panjang total Ikan Red Devil (Amphilophus sp) yang tertangkap di perairan Desa Songan cendrung memiliki ukuran panjang mencapai $13,5 \mathrm{~cm}$ hal ini kemungkinan berkaitan dengan kondisi di perairan Desa Songan yang memiliki subtrat berpasir dan banyak ditumbuhi eceng gondok serta dekat dengan permukiman penduduk dan kontak langsung dengan lahan pertanian. Berbeda halnya dengan di perairan Desa Trunyan yang ukuran panjang totalnya paling rendah yaitu $11,7 \mathrm{~cm}$. Di perairan Desa Trunyan yang memiliki subtrat berlumpur, tidak ada tumbuhan air jenis eceng gondok tetapi juga dekat dengan permukiman dan pertanian. Adanya tanaman eceng gondok dan subtrat berpasir sangat mendukung habitat Ikan Red Devil. Ikan Red Devil menyakai jenis-jenis pakanseperti: ikan, crustasea, detritus, fitoplakton, Annelida, chironomus sp dan serangga (Ariasari et al., 2018).

Struktur ukuran Ikan Red Devil (Amphilophus sp) yang tertangkap dengan menggunakan alat tangkap pancing, mempunyai ukuran yang berbeda di setiap lokasi penelitian, yaitu dengan kisaran antara 8,5 - 9,3 cm. Hal tersebut dikarenakan penggunaan alat tangkap pancing yang memiliki size 2-4 inci, dan pengoperasian alat tangkap pancing dilakukan di pinggir danau. Kondisi substrat pada lokasi penelitian mempunyai karakteristik yang berbeda, seperti berpasir, berbatu, dan berlumpur dengan kedalaman yang beragam serta banyak tumbuhan air jenis eceng gondok yang terdapat di beberapa lokasi penelitian.

Tabel 2. Ukuran Rata-Rata Panjang Total (PT), Panjang Standar (PS) serta Berat Ikan Red Devil (Amphilophus sp) pada Alat Tangkap Pancing.

\begin{tabular}{clcccc}
\hline No & Perairan & $\begin{array}{c}\text { Jumlah } \\
(\text { Individu })\end{array}$ & $\begin{array}{c}\text { Rata-Rata PT } \\
(\mathrm{cm})\end{array}$ & $\begin{array}{c}\text { Rata-Rata PS } \\
(\mathrm{cm})\end{array}$ & $\begin{array}{c}\text { Berat } \\
(\mathrm{g})\end{array}$ \\
\hline 1. & Songan & 79 & 9,1 & 7,2 & 14,2 \\
2. & Batur & 96 & 8,7 & 6,7 & 12,3 \\
3. & Kedisan & 69 & 8,5 & 6,7 & 12,6 \\
4. & Abang & 71 & 8,8 & 6,9 & 12,3 \\
5. & Trunyan & 47 & 9,3 & 7,3 & 16,5 \\
\hline
\end{tabular}

Tabel 3. Ukuran Rata-Rata Panjang Total (PT), Panjang Standar (PS) serta Berat Ikan Red Devil (Amphilophus sp) pada Alat Tangkap Jaring.

\begin{tabular}{clcccc}
\hline No & Perairan & $\begin{array}{c}\text { Jumlah } \\
(\text { Individu })\end{array}$ & $\begin{array}{c}\text { Rata-Rata PT } \\
(\mathrm{cm})\end{array}$ & $\begin{array}{c}\text { Rata-Rata PS } \\
(\mathrm{cm})\end{array}$ & $\begin{array}{c}\text { Berat } \\
(\mathrm{g})\end{array}$ \\
\hline 1. & Songan & 54 & 13,5 & 11,1 & 48,8 \\
2. & Batur & 73 & 12,4 & 9,8 & 37,9 \\
3. & Kedisan & 52 & 11,9 & 9,5 & 34,4 \\
4. & Abang & 58 & 12,2 & 9,8 & 37,0 \\
5. & Trunyan & 32 & 11,7 & 9,2 & 31,4 \\
\hline
\end{tabular}

\subsection{Hubungan Panjang Bobot Ikan Red Devil (Amphilophus sp)}

Hasil perhitungan hubungan panjang bobot ikan di perairan Desa Songan yang menggunakan alat tangkap pancing yaitu nilai $b$ sebesar 2,740 dengan nilai koefisien determinasi $\left(\mathrm{R}^{2}\right)$ sebesar 0,885 . Sedangkan hasil perhitungan dengan menggunakan alat tangkap jaring yaitu nilai b sebesar 2,381 dan nilai koefisien determinasi $\left(\mathrm{R}^{2}\right)$ sebesar 0,795. Hubungan panjang bobot ikan di perairan Desa Batur yang menggunakan alat tangkap pancing memiliki nilai b sebesar 3,038 dengan nilai koefisien determinasi $\left(\mathrm{R}^{2}\right)$ sebesar 0,887 . Sedangkan hubungan panjang bobot ikan yang menggunakan alat tangkap jaring memiliki nilai b sebesar 2,982 dengan nilai koefisien determinasi $\left(\mathrm{R}^{2}\right)$ sebesar 0,867 .

Hasil perhitungan hubungan panjang bobot ikan di perairan Desa Kedisan yang menggunakan alat tangkap pancing memiliki nilai b sebesar 2,984 dan nilai koefisien determinasi ( $\mathrm{R}^{2}$ ) sebesar 0,942. Ikan Red Devil (Amphilophus sp) yang tertangkap dengan menggunakan alat tangkap jaring memiliki nilai $b$ sebesar 2,300 dengan nilai koefisien determinasi $\left(\mathrm{R}^{2}\right)$ sebesar 0,718. Analisis hubungan panjang bobot ikan di perairan Desa Abang yang menggunakan alat tangkap pancing yaitu nilai b sebesar 2,750 dengan nilai koefisien determinasi $\left(\mathrm{R}^{2}\right)$ sebesar 0,908 . Sedangkan hasil analisis hubungan panjang bobot ikan 
dengan menggunakan alat tangkap jaring yaitu nilai b sebesar 2,912 dan nilai koefisien determinasi $\left(\mathrm{R}^{2}\right)$ sebesar 0,878 .

Hubungan panjang bobot ikan di perairan Desa Trunyan yang menggunakan alat tangkap pancing, memiliki nilai $b$ sebesar 3,178 dengan nilai koefisien determinasi $\left(\mathrm{R}^{2}\right)$ sebesar 0,952 . Hasil analisis hubungan panjang bobot ikan dengan menggunakan alat tangkap jaring yaitu, nilai b sebesar 3,104 dengan nilai koefisien determinasi $\left(\mathrm{R}^{2}\right)$ sebesar 0,919 (Gambar 3).
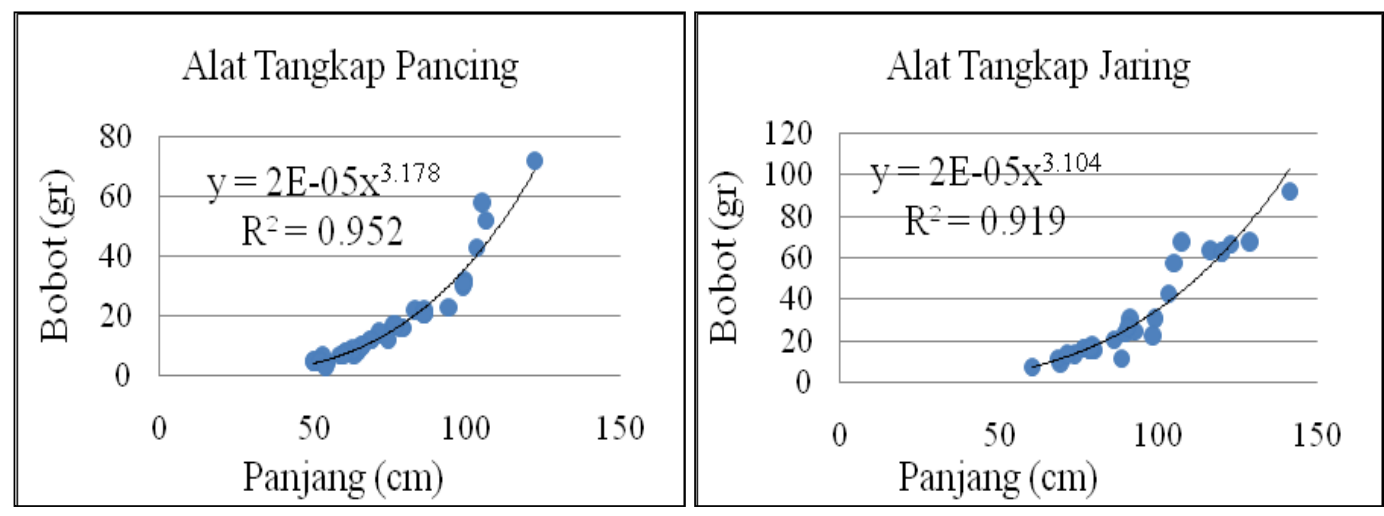

Gambar 2. Grafik hubungan panjang bobot ikan dengan koefisien determinasi tertinggi di perairan Desa Trunyan

Di perairan Desa Songan yang menggunakan alat tangkap pancing maupun jaring memiliki pola pertumbuhan allometrik negatif. Dimana, pertambahan panjang Ikan Red Devil (Amphilophus sp) lebih dominan daripada pertambahan bobotnya. Sehingga ikan yang tertangkap pada perairan ini fisiknya terlihat pipih. Ketidakseimbangan pola pertumbuhan ikan tersebut antara panjang dan juga beratnya kemungkinan disebabkan oleh limbah pertanian yang menyebabkan subtrat berubah menjadi warna hitam pekat dan mengeluarkan bau busuk sehingga menyebabkan kualitas perairan kurang baik. Selain itu, kemungkinan disebabkan oleh banyaknya aktivitas masyarakat seperti penangkapan ikan yang dilakukan oleh masyarakat setempat. Hal ini sesuai dengan pendapat Suruwaky dan Gunaisah (2013), yang menyatakan bahwa ketidakseimbangan pada pertumbuhan panjang maupun berat ikan bisa disebabkan oleh eksploitasi ikan secara berlebihan melalui tangkapan nelayan sehingga mempengaruhi panjang dan berat.

Sedangkan pola pertumbuhan panjang dan berat Ikan Red Devil (Amphilophus sp) yang terdapat di perairan Desa Batur memiliki pola pertumbuhan yang berbeda antara alat tangkap pancing dan jaring. Pada alat tangkap pancing nilai $b>3$ yang berarti pola pertumbuhan allometrik positif. Dimana, pertumbuhan bobot lebih dominan daripada pertambahan panjang. Sehingga ikan yang diperoleh terlihat gemuk/montok. Hal tersebut, kemungkinan disebabkan oleh kondisi lingkungan yang mendukung seperti substrat yang berbatu dan terdapat banyak tumbuhan air di tepian danau. Selain itu kemungkinan juga disebabkan oleh melimpahnya pakan alami yang disediakan oleh alam, seperti ikan-ikan kecil dan busukan dari tumbuhan air. Hal ini sesuai dengan pernyataan Rosali dan Isa (2012), pertumbuhan ikan dipengaruhi oleh faktor biologis (pertumbuhan gonad dan jenis kelamin), lingkungannya, (kecukupan makanan dan kondisi perairan), dan teknik pelestarian serta perbedaan lama pengamatan dari spesimen yang tertangkap.

Tetapi pada alat tangkap jaring, nilai $b<3$ yang berarti memiliki pola pertumbuhan allometrik negatif sehingga memiliki pola pertumbuhan yang berbeda pada satu titik. Perbedaan nilai $b$ tersebut dapat disebabkan oleh perbedaan jumlah dan variasi ikan yang diamati (Okgerman, 2005). Hubungan panjang dan bobot ikan di perairan Desa Kedisan memiliki pola pertumbuhan yang sama antara alat tangkap pancing dan jaring. Ikan Red devil (Amphilophus sp) yang tertangkap memiliki b $<3$ yang berarti memiliki pola pertumbuhan allometrik negatif. 
Panjang dan bobot ikan yang ditemukan di perairan Desa Abang memiliki pola pertumbuhan yang sama dengan perairan Desa Kedisan pada kedua alat tangkap yaitu allometrik negatif. Pertumbuhan ini menunjukkan bahwa pertambahan panjang ikan lebih cepat dibandingkan pertambahan bobotnya, sehingga ikan terlihat pipih. Pola pertumbuhan Ikan Red devil (Amphilophus sp) di perairan Desa Trunyan memiliki pola pertumbuhan yang sama pada kedua alat tangkap. Dimana, nilai $b>3$ yang berarti memiliki pola pertumbuhan allometrik positif (Gambar 3). Hal ini menunjukkan bahwa pertambahan berat lebih cepat dibandingkan pertambahan panjangnya. Sehingga fisik ikan terlihat montok atau gemuk. Sehingga dapat diduga bahwa terdapat ketersediaan makanan yang cukup dan kondisi lingkungan sekitar. Menurut Muchlisin et al. (2010), bahwa besar kecilnya nilai b dipengaruhi oleh prilaku ikan, misalnya ikan yang berenag aktif menunjukkan nilai $b$ yang lebih rendah dibandingkan dengan ikan yang berenag pasif. Hal ini berkaitan dengan lokasi energi yang dikeluarkan untuk pergerakan dan pertumbuhan.

\subsection{Kondisi fisika dan kimia perairan}

Parameter fisika dan kimia perairan yang diukur dalam penelitian ini meliputi suhu, $\mathrm{DO}, \mathrm{pH}$, dan kecerahan perairan. Suhu yang diperoleh di Danau Batur berkisar antara $26,3-29,1^{\circ} \mathrm{C}$ (Tabel 4). Nilai suhu yang diperoleh hampir sama dengan hasil penelitian yang diperoleh oleh Sipriana (2012), yang melakukan penelitian di Danau Tondano, Kabupaten Minahasa. Dimana, kisaran suhu yang diperoleh berkisar antara $24,7-28,3^{\circ} \mathrm{C}$. Kisaran nilai suhu yang diperoleh masih berada pada kondisi yang optimum bagi kelangsungan hidup Ikan Red Devil (Amphilophus sp). Menurut Mulyanto (1992), menyatakan bahwa suhu yang baik untuk kehidupan ikan di daerah tropis berkisar antara $25-32^{\circ} \mathrm{C}$.

Oksigen terlarut (DO) merupakan suatu indikator kualitar air, kondisi ekologi, produktivitas, dan kesehatan perairan (Wetzel, 2001). Kisaran oksigen terlarut di perairan Danau Batur berkisar antara 5,36 $\mathrm{mg} / \mathrm{L}-6 \mathrm{mg} / \mathrm{L}$ (Tabel 4). Nilai tersebut masih cukup baik bagi kelangsungan hidup Ikan Red Devil (Amphilophus sp). Hal ini sesuai dengan pendapat Barus (2004), yang menyatakan bahwa nilai oksigen terlarut yang optimal adalah lebih dari $3 \mathrm{mg} / \mathrm{L}$.

Hasil pengukuran pH di Danau Batur berkisar antara 7,2-7,8 (Tabel 4). Kisaran nilai pH tersebut tergolong cukup setabil dan optimal bagi kelangsungan hidup ikan. Secara umum nilai $\mathrm{pH}$ yang optimal untuk pertumbuhan fitoplankton berkisar antara 7-8,5 (Barus, 2004). Sedangkan nilai kecerahan berkisar antara 87,1-147,8 $\mathrm{cm}$ (Tabel 4). Hasil yang diperoleh menunjukkan cahaya matahari masih dapat menembus perairan Danau Batur. Menurut Zulfia dan Aisyah (2013), nilai kecerahan dalam perairan dipengaruhi oleh warna air, kekeruah, waktu pengukuran, dan padatan tersuspensi yang ada didalam perairan.

Tabel 4. Hasil pengukuran parameter kualitas air.

\begin{tabular}{lcccc}
\hline \multicolumn{1}{c}{ Lokasi Pengambilan Sampel } & $\begin{array}{c}\text { Suhu } \\
\left({ }^{\circ} \mathrm{C}\right)\end{array}$ & $\begin{array}{c}\mathrm{DO} \\
(\mathrm{mg} / \mathrm{L})\end{array}$ & $\mathrm{pH}$ & $\begin{array}{c}\text { Kecerahan } \\
(\mathrm{cm})\end{array}$ \\
\hline Desa Songan & 26,3 & 5,7 & 7,3 & 87,1 \\
Desa Batur & 28,7 & 6,0 & 7,2 & 121,7 \\
Desa Kedisan & 29,1 & 5,3 & 7,8 & 103,2 \\
Desa Abang & 28,9 & 5,4 & 7,3 & 147,8 \\
Desa Trunyan & 28,6 & 5,3 & 7,3 & 129,5 \\
\hline
\end{tabular}

\section{Simpulan}

Struktur ukuran Ikan Red Devil (Amphilophus sp) yang ditangkap dengan jaring, mempunyai kisaran panjang total (PT) $11,7 \mathrm{~cm}-13,5 \mathrm{~cm}$, dan cendrung memiliki nilai seragam sebagai akibat dari penggunaan ukuran mata jaring yang sama. Pada alat tangkap pancing dengan mata kail berukuran 2-4 inci, memperoleh hasil tangkapan dengan kisaran panjang total (PT) yang lebih pendek yaitu 8,5-9,3 cm. Pola pertumbuhan Ikan Red Devil (Amphilophus $s p$ ) berdasarkan analisis panjang dan bobot menunjukkan pola pertumbuhan allometrik positif dan allometrik negatif. 


\section{Ucapan Terimakasih}

Penulis mengucapkan terima kasih kepada dosen pembimbingdan penguji yang telah membimbing penulis selama ini.

\section{Daftar Pustaka}

Ariasari A., Helmiati S., \& Setyobudi E. (2018). Food Preference of Red Devil (Amphilophus sp) in the Sermo Reservoir, Kulon Progo Regency. IOP Conf. Series: Earth and Environmental Science. 139 pp.

Bahri, S., Sayyid, A.El-R., \& Kurnianda, V. (2018). Distribusi dan Kelimpahan Apogonidae pada Ekosistem Lamun di Teluk Ahmad Rhang Manyang, Kabupaten Aceh Besar. Jurnal Ilmiah Mahasiswa Kelautan dan Perikanan Unsyiah, 3(2): 83-91.

Barus, T.A. (2004). Pengantar Limnologi Studi Tentang Ekosistem Air Daratan. Medan: USU Press. Hlm: 33-35.

Brower, J.E., Zar, J.H, \& Von Ende, C.N. (1990). Field and Laboratory Methods for General Ecology. Iowa: Wim.C. Brown Co.Pub. Dubuque. 237 pp.

Conkel D. (1993). Cichlids of North and Central America. TFH Publications, Inc., Neptune City. 191 p.

Effendie, I.M. (2002). Biologi Perikanan. Yogyakarta: Yayasan Pustaka Nusantara

Fatma, R. A. (2017). Pengolahan Red Devil (Amphilophus Labiatus) Waduk Sermo Menjadi Asam Amino Sebagai Sumber Nutrisi Tanaman Durian (Durio Zibethinus). Jurnal Agroteknologi, 5(1): 42-46.

Habibie, S.A., Djumanto, \& Rustadi. (2015). Penggunaan otolit untuk penentuan umur dan waktu pemijahan ikan red devil, Amphilophus labiatus [Günther, 1864] di Waduk Sermo, Yogyakarta. Jurnal Iktiologi Indonesia, 15(2): 87-98.

Ludwig JA, Reynolds JF. 1988. Statistical Ecology: A Primer on Methods and Computing. Singapore (SG): John Wiley and Sons.

Muchlisin, Z., Musman, M., \& Azizah, M.N.S. (2010). Leng Weight Relationships and Condition Factors of Two Theretened Fishies, Rasbora tawarensis and Proporopuntius twarensis, endemic to Lake Laut Tawar. Aceh Province, Indonesia. Journal of Applied Icthiology, 26: 949-953

Mulyanto, (1992). Manajemen Perairan. LUW-UNIBRAW. Fisheries Project. Universitas Brawijaya. Malang

Okgerman, H. (2005). Seasonal Variation of The Length Weinght and Condition Factor of Rudd (Scardinius erytrophthalamus L.) in Spanca Lake. International journal of Zoological Research. 1(1): $6-10$

Rosali, N.A.M., \& Isa, M.M. (2012). Length-weight and length-lemght relationship of longsnouted cathfish, Plicofollis argropleuron (Valenciennes, 1840) in the Northern Part of Peninsular Malaysia. Journal Tropical Life Science Reasea. 23(2): 59-65

Sipriana, S.T. (2012). Kualitas Air Pada Lokasi Budidaya Ikan di Perairan Desa Eris, Danau Tondano, Kabupaten Minahasa. Jurnal Perikanan dan Kelautan Tropis.VII(1): 2012

Suin.M.N. (2002). Metode Eklogi. Universitas Andalas, Padang. (2): 56-61 hlm.

Suruwaky, A.M., \& Gunaisah, E. (2013). Identifikasi Tingkat Eksploitasi Sumber Daya Ikan Kembung Lelaki (Restrelliger Kanagurta) ditinjau dari Hubungan Panjang-Berat. Jurnal Akuatika. IV(2): 131140

Wetzel, R.G. (2001). Limnology. 3rd. Saunders Company. Philadelphia. Toronto. London. 767 p.

Wijaya, D. A. F.S., \& Tjahjo, D.W. H. (2012). Kajian kualitas perairan dan potensi produksi sumberdaya ikan di Danau Batur, Bali. Prosiding Seminar Nasional Lmnologi VI Tahun 2012: 386 - 399 
Zulfia, A., \& Aisyah. (2013). Status Tropik Perairan Rawa pening Ditinjau dari Kandungan Unsur Hara (NO3) dan PO4 serta Klorofil-a. Jurnal Bawal. 5(3): 189-199. 